\title{
ANALISIS FAKTOR ELEKTRONIK WORD OF MOUTH (EWOM) DALAM MEMPENGARUHI KEPUTUSAN BERKUNJUNG WISATAWAN
}

\author{
Aulian Humaira \\ Lili Adi Wibowo
}

\begin{abstract}
It has been acknowledged that tourism is a dynamic sector which is staying at a big competition globally. More countries around the world are competing to develop the tourism potential to be well-known. Asian Pasific region has high commitment to win the global tourism competition, proved by the average calculation of tourist visits, which is dominated by Asian Pasific than other regions. Malaysia is the only country in South East Asian which counted in The World's Top Destination. It has many tourism destinations. One of them is Langkawi Island that is a well-known and popular tourism destination which successfully achieved a lot of awards. The visit growth in Langkawi Island has instability, and the most decreasing growth appeared in 2007 to 2009 amount of 1, 3\% and followed by 2, 5\% from 2009 to 2010. The decrease was caused by the lower visit intention of tourist or to be called as future behavioral intention. Visit decision is motivated by push and pull factors, which come from the internal of tourist as well as the external factors of tourism destination. The strategy by Langkawi Island authority to increase the visit decision is by implementing electronic word of mouth (EWOM) which shared through social media. EWOM consists of tie strength, homophile, trust, normative influence and informative influence. This research used descriptive and verified method. The respondents are tourists of Langkawi Island with the number of sample 100 tourists. This research is using Partial Least Square (PLS) analyzing technique. Independent variable is electronic word of mouth with its dimensions are tie strength (X1), homophile (X2), trust (X3), normative influence (X4), and informative influence (X5). Furthermore, the tourist visit decision is the dependent variable $(Y)$. The result shows that EWOM factors are placed in high category whereas it has a weak positive impact upon the tourist's visit decision in Langkawi Island, Malaysia. PLS result shows that the dominant factors of EWOM are homophile and normative influence. Meanwhile, the impact of EWOM to the tourist visit decision is 0,284 and the residue by other factors, which is not studied for this research.
\end{abstract}

Keywords: Electronic Word of Mouth, Visit Decision

\section{PENDAHULUAN}

\subsection{Latar Belakang Penelitian}

Jumlah destinasi pariwisata di dunia yang semakin berkembang mengakibatkan adanya persaingan besar-besaran secara internasional. Kawasan Asia Pasifik diketahui menjadi salah satu kawasan yang memiliki komitmen tinggi untuk memenangkan kompetisi pariwisata global dengan rata-rata pertumbuhan pangsa pasar kedua terbesar setelah Amerika yang berada di angka 5,9\% dari tahun 2005 hingga 2011. Satu-satunya negara di Asia Tenggara yang masuk ke dalam peringkat sepuluh besar dalam daftar World's Top Tourism Destinations adalah Malaysia. Dalam perkembangannya Malaysia menguasai presentase paling banyak di antara Negara Asia Tenggara lainnya yaitu sebesar $11,4 \%$.

Salah satu destinasi pariwisata di Malaysia yang sukses meraih berbagai macam prestasi dan penghargaan baik secara tingkat nasional maupun internasional adalah Pulau Langkawi. Pulau Langkawi terletak di Wilayah bagian Kedah, Malaysia dan dikenal dengan julukan "Rice Bowl of Malaysia”. Informasi mengenai Pulau Langkawi dapat dengan mudah ditemukan di internet, seperti melalui media sosial, forum pariwisata, social networking sites, travel blog, dan lainnya.

Dalam target 2011-2015, Perdana Menteri Malaysia akan menjadikan Langkawi sebagai salah satu Kepulauan terbaik di dunia dan mendatangkan wisatawan sebanyak empat juta di akhir tahun 2015. Keseriusan Pemerintah Malaysia untuk menjadikan Pulau Langkawi sebagai Pulau terbaik di dunia dapat dilihat dari kunjungan wisatawan yang meningkat dari tahun ke tahun seperti pada Tabel 1 berikut:

TABEL 1

JUMLAH KUNJUNGAN WISATAWAN KE PULAU LANGKAWI TAHUN 2007-2013

\begin{tabular}{|c|c|}
\hline Tahun & $\begin{array}{c}\text { Jumlah } \\
\text { Kunjungan } \\
\text { Wisatawan }\end{array}$ \\
\hline 2007 & 2,3 Juta Jiwa \\
\hline 2008 & 2,3 Juta Jiwa \\
\hline 2009 & 2,5 Juta Jiwa \\
\hline 2010 & 2,4 Juta Jiwa \\
\hline 2011 & 2,8 Juta Jiwa \\
\hline 2012 & 3,1 Juta Jiwa \\
\hline 2013 & 3,4 Juta Jiwa \\
\hline
\end{tabular}

Sumber: www.lada.gov.my, 2013. 
Tabel 1 menunjukan bahwa jumlah kunjungan wisatawan ke Pulau Langkawi dari tahun 2007 hingga 2013 mengalami kenaikan. Namun jika diperhatikan, pertumbuhan kunjungan wisatawan mengalami ketidakstabilan dan terdapat penurunan pertumbuhan sebesar $1,3 \%$ di tahun 2008 dan 2,5\% di tahun 2010. Penurunan ini cukup besar dalam jangka waktu selama dua tahun, sedangkan pertumbuhan yang terjadi dari tahun 2000 hingga 2009 secara akumulatif hanya sebesar 3,6\% (www.lada.gov.my, 2013). Oleh karena itu penurunan pertumbuhan ini menjadi ancaman bagi Langkawi dalam proses meraih target sebagai kepulauan terbaik di dunia.

Pulau Langkawi merupakan destinasi wisata yang terkenal di dunia internet. Informasi wisatanya dapat diakses dengan bebas dan mendalam berasal dari situs resmi maupun tidak resmi. Meskipun Langkawi memiliki situs resmi, namun keberadaan media sosial, blog, microblogging, social networking sites tidak dapat dibantah memiliki peranan penting dalam penyebarluasan informasi mengenai Pulau Langkawi. Selain itu, situs non pemerintah lainnya seperti tripadvisor menjadi salah satu media yang popular bagi wisatawan dalam proses pencarian informasi yang berkaitan dengan pariwisata di Pulau Langkawi. Wisatawan dapat dengan leluasa bertukar informasi, memberikan opini, berkomentar seputar perjalanan maupun memberi tanggapan dalam sebuah topik di dalam forum seperti tripadvisor sehingga menciptakan komunikasi interaktif antar wisatawan terkait pariwisata di Pulau Langkawi. Proses seperti ini disebut sebagai WOM yang diterapkan melalui media elektronik (Elektronic Word of Mouth). EWOM yang terjadi mengenai Pulau Langkawi pada dasarnya bervariasi, karena EWOM tersebut berasal dari ide dan pengalaman wisatawan yang berbeda pada saat berkunjung ke Pulau Langkawi. Oleh karena itu, perlu diketahui faktor EWOM yang bagaimana yang berkontribusi dalam membentuk EWOM dan bagaimana pengaruhnya terhadap keputusan berkunjung wisatawan.

Berdasarkan latar belakang tersebut, maka perlu dilakukan suatu penelitan mengenai "Analisis Faktor Elektronik Word of Mouth (EWOM) dalam Mempengaruhi Keputusan Berkunjung Wisatawan".

\subsection{Rumusan Masalah}

Berdasarkan latar belakang di atas, maka dapat dirumuskan masalah penelitian sebagai berikut:

1. Bagaimana Elektronik Word of Mouth (EWOM) yang tersebar di media elektronik mengenai Pulau Langkawi?
2. Bagaimana keputusan berkunjung wisatawan yang terdiri dari push and pull factors di Pulau Langkawi?

3. Faktor mana dari Elektronik Word of Mouth (EWOM) yang terdiri dari tie strength, homohily, trust, normative influence dan informative influence yang dominan dalam membentuk EWOM?

4. Bagaimana faktor-faktor EWOM dalam mempengaruhi keputusan berkunjung wisatawan?

\subsection{Tujuan Penelitian}

Berdasarkan rumusan masalah di atas, maka tujuan penelitian ini adalah untuk memperoleh hasil temuan mengenai:

1. Elektronik Word of Mouth yang tersebar di media elektronik mengenai Pulau Langkawi

2. Keputusan berkunjung wisatawan yang terdiri dari push and pull factors di Pulau Langkawi

3. Faktor dari EWOM yang terdiri dari tie strength, homohily, trust, normative influence dan informative influence yang dominan dalam membentuk EWOM

4. Bagaimana faktor EWOM dalam mempengaruhi keputusan berkunjung wisatawan

\subsection{Kegunaan Penelitian}

Penelitian penelitian ini diharapkan dapat memberikan manfaat kegunaan teoritis maupun praktis:

\section{Kegunaan Teoritis}

Secara teoritis, hasil penelitian ini diharapkan dapat memperluas kajian ilmu pemasaran, khususnya di bidang pemasaran destinasi

\section{Kegunaan Praktis}

Secara praktis hasil penelitian ini diharapkan dapat memberikan kontribusi terhadap pariwisata Pulau Langkawi sebagai destinasi wisata yang memiliki banyak prestasi di mata dunia agar mampu menjadi panutan untuk negara-negara berkembang lainnya di Asia Tenggara khususnya Indonesia khususnya dengan implementasi EWOM yang dilakukan

\section{KAJIAN PUSTAKA}

\subsection{Konsep Elektronik Word of Mouth sebagai Strategi Pemasaran}

Dalam suatu penelitian yang dilakukan oleh Baloglu dan McClearly (1999) meneliti mengenai rekomendasi WOM (Word of Mouth) sebagai salah satu sumber informasi yang akurat dalam menentukan citra destinasi wisata. Rekomendasi WOM dari teman dan kerabat dekat adalah sumber 
yang terpenting yang dapat membentuk citra perjalanan wisata. Karena berasal dari rekan dan kerabat terdekat, WOM menjadi sumber yang terpercaya dibandingkan sumber yang lain karena berisi informasi yang cenderung lebih jujur dan akurat sehingga semakin banyak WOM yang didapat oleh wisatawan, semakin kuat pula pembentukan citra dari sebuah destinasi. WOM berfungsi sebagai saluran komunikasi yang memberikan informasi secara jujur, akurat yang berasal dari kerabat atau orang terdekat sehingga secara langsung dapat mempengaruhi kesan seseorang terhadap suatu destinasi wisata.

EWOM merupakan digitalisasi dari WOM tradisional. WOM disampaikan secara langsung dari satu pihak ke pihak lain sedangkan penyampaian EWOM membutuhkan media perantara yaitu melalui media elektronik. WOM pada dasarnya berisikan informasi yang akurat, emosional, lebih jujur dan hanya dapat diperoleh sekali saja karena prosesnya terjadi langsung dan berasal dari sumber yang dipercaya contohnya keluarga. Sedangkan EWOM belum tentu berisi informasi yang akurat karena berasal dari sumber yang cenderung tidak dikenal (misalnya sesama pengguna internet dan media sosial tertentu) namun mempunyai kelebihan yaitu dapat disimpan sebagai arsip jika sewaktu-waktu dibutuhkan dan penyebarannya pun sangat cepat bahkan dapat meluas secara global.

Beberapa penelitian mengenai EWOM (Litvin, 2007; Litvin, Goldsmith, dan Pan, 2008; Hennig dan Thurau, 2010; Chu dan Kim, 2011; Ye dan Yushe, 2009; Goyette, Ricard, Bergeron dan Marticotte, 2010; Thor, 2013; See, Ho dan Lee, 2013) umumnya membahas mengenai sebuah produk dari perusahaan sehingga minimnya ditemukan penelitian EWOM di lingkup pariwisata. Konsumen biasanya menerima dan merespon pesan-pesan EWOM sebagai sumber terpercaya dari informasi yang menarik dan berguna (Bickart dan Schindler, 2001; Gruen, 2006) dalam Strutton dan Taylor (2012:819). Litvin, Goldsmith dan Pan (2008:462) mengungkapkan bahwa EWOM akan mengubah struktur informasi perjalanan dan kemudian mengubah pengetahuan dan persepsi wisatawan terhadap beragam produk wisata. Kini semakin berkembang wisatawan yang memanfaatkan teknologi internet untuk memperoleh informasi wisata, berbagi cerita dan opini tentang pengalaman perjalanannya ke berbagai social networking sites. Sebagaimana penelitian oleh Xiang dan Gretzel (2010:181) yang menyatakan bahwa di masa kini pemasaran pariwisata berfokus pada pemanfaatan media sosial untuk menciptakan citra positif dan WOM untuk destinasi wisata dan juga para pebisnis. Hal tersebut dikuatkan oleh Parra-Lopez (2011:640) yang mengungkapkan hal tersebut sebagai hal yang umum bahwa media elektronik memberikan manfaat sebagai wadah untuk saling berbagi foto, video ke blog pribadi, memberikan rating, mengevaluasi, melihat peta secara online dan sebagainya untuk berbagi dan merekomendasikan kepada sesama pengguna.

Chu dan Kim (2011) menyatakan dimensi EWOM yang ada di lingkup Social Networking Sites (SNSs) yaitu Tie Strength, Homophily, Trust, Normative Influence, dan Informational Influence. Tie Strength merupakan potensi ikatan yang terjalin antara anggota dalam sebuah jaringan. Homophily merupakan derajat kesamaan seseorang dalam kondisi tertentu, misalnya kesamaan pikiran dalam menerima pesan. Trust adalah rasa percaya dari diri pengguna terhadap informasi yang diterima, juga berarti mengandalkan sesuatu kepada rekan bertukar pendapat. Normative influence merupakan kecenderungan untuk berharap orang lain berperilaku sama dengan yang kita rasakan, mudah terpengaruh oleh opini dan persetujuan sosial. Sedangkan Informational influence adalah kecenderungan untuk menerima informasi yang disampaikan dalam pencarian barang dan jasa.

EWOM menghadirkan bentuk baru komunikasi antara penerima dan pengirim. Seperti yang digambarkan oleh Cheung dan Thadani (2010:332) terdapat stimulus, communicator, receiver, dan response. Stimulus merupakan pesan yang dikirimkan yang mengandung pesan positif, negatif maupun netral. Biasanya stimulus ini berupa konsistensi dan banyaknya ulasan dari penulis lainnya. Communicator berarti seseorang yan menyampaikan pesan, biasanya melibatkan keahlian, ketertarikan dan kesamaan. Pesan yang disampaikan melalui EWOM tidaklah selalu bersifat personal sehingga isinya dapat dinikmati oleh siapapun. Receiver yang berarti orang yang memberi respon terhadap komunikasi EWOM. Respon yang terjadi berbeda-beda antara satu penerima dengan yang lain karena melibatkan rasa ingin tahu, kepercayaan, fokus pencarian, ikatan sosial dan kesamaan. Response berarti tanggapan atau reaksi yang dihasilkan dari komunikasi antara pengirim dan penerima. Faktor yang terkait adalah perilaku penerima, adaptasi informasi, kepercayaan, pembelian, kesetiaan, dan kehadiran sosial. (Dellarocas, Zhang dan Award, 2007; Zhand dan Watts, 2008; Cheung, Luo, Sia dan Chen, 2009). Dari proses komunikasi dari Cheung dan Thadani, terlihat bahwa pada dasarnya pesan yang diberikan tidak hanya berasal dari pengirim namun dapat berasal juga dari penerima dalam satu waktu sehingga proses komunikasi EWOM berjalan secara interaktif menghasilkan respon yang berbeda-beda. 


\subsection{Keputusan Berkunjung}

Kotler, Bowen dan Maken (2014:166) mengemukakan bahwa, "Perilaku pembelian konsumen merupakan perilaku pembelian dari individual yaitu konsumern akhir yang membeli barang dan jasa untuk konsumsi pribadi". Jadi perilaku konsumen di sini berarti tentang pemikiran, pertimbangan, perbuatan dan perasaan konsumen pada saat memilih sebuah produk untuk memuaskan kebutuhan dan keinginannya.

Grifin dan Ebert (2006:283) mendefinisikan "Keputusan pembelian sebagai keputusan yang didasari oleh motif rasional, motif emosional atau keduanya. Motif rasional melibatkan evaluasi logis dari atribut produk, motif emosional melibatkan faktor non objektif dan termasuk imitasi dan keindahan lainnya".

Shaw dan William (1992) dalam Pitana dan Gayatri (2005:73) mengelompokkan tiga perilaku wisatawan. Yang pertama adalah impulse buyers, yaitu mereka yang tertarik pada harga rendah yang ditawarkan oleh agen perjalanan. Repeat buyers, adalah mereka yang kembali ke destinasi yang sama dalam jangka waktu tertentu, dan yang ketiga adalah meticulous planners yaitu mereka yang berusaha mencari informasi lengkap dan mutakhir serta terperinci untuk membuat perbandungan. Umumnya proses perencanaan tersebut berlangsung lama untuk mengurangi tingkat resiko ketika berkunjung dengan cara pencarian informasi secara detail. Jalilvand, Samiei, Dini dan Manzari (2012:137) menyatakan dalam penelitiannya bahwa wisatawan yang menilai positif suatu destinasi akan berpengaruh terhadap kemungkinan berkunjung ke destinasi tersebut. Maka dari penelitian-penelitian tersebut dapat disimpulkan bahwa keputusan berkunjung dipengaruhi oleh citra sebuah destinasi yang dinilai oleh wisatawan itu sendiri.

Tahap-tahap keputusan berkunjung wisatawan menurut Schmoll (1977) ada empat yaitu 1) the travel stimuli; yang berarti pengaruh lingkungan eksternal seperti promosi, 2) certain external variables; yang berarti tahapan mengenai kepercayaan wisatawan, citra destinasi, pengalaman wisatawan, 3) personal and social factors; yang berarti faktor pribadi dan sosial dimana masalah sosial berpengaruh pada kegiatan wisata seperti status sosial ekonomi, karakter individu, dan 4) the features of touristic services; merupakan kualitas pelayanan, perbandingan harga dan nilai, fasilitas dan atraksi yang ditawarkan.

Penelitian yang dilakukan oleh Moscardo (1996:109) mengungkapkan proses pemilihan destinasi wisata yaitu 1) Searching information; 2) Set of alternatives; 3 ) Evaluating alternatives; dan 4) Choosing the destination. Elemen utama dalam proses pemilihan tersebut adalah perilaku konsumtif wisatawan dan cara wisatawan mencari informasi destinasi wisata mana yang dapat memuaskan kebutuhan berwisatanya. Banyak faktor yang mempengaruhi proses pemilihan destinasi wisata di atas yaitu pengalaman wisatawan, karakteristik individu, fasilitas destinasi, promosi, citra, sumber informasi, kendala waktu, biaya dan resiko yang diterima.

Prayag (2013: 674) melakukan penelitian mengenai minat wisatawan terhadap suatu destinasi, yaitu push dan pull factors. Push merupakan faktor pendorong yang berasal dari dalam diri yaitu kebutuhan dan keinginan wisatawan, sedangkan pull merupakan faktor penarik yang berasal dari destinasi wisata untuk menawarkan potensi-potensi yang dimiliki. Lee (2009) menyatakan bahwa faktor pendorong tersebut berdampak terhadap kepuasan wisatawan meskipun secara tidak langsung mempengaruhi perilaku mendatang wisatawan. Penelitian ini menggunakan konsep Prayag (2013:674) untuk melihat faktor pendorong dan faktor penarik tersebut dan melihat faktor mana yang memberikan kontribusi paling besar ketika wisatawan berkunjung ke destinasi.

\subsection{Paradigma Penelitian}

Untuk menjawab keseluruhan permasalahan seperti yang dijelaskan dalam rumusan masalah, maka paradigma penelitian digambarkan pada Gambar 2 berikut:

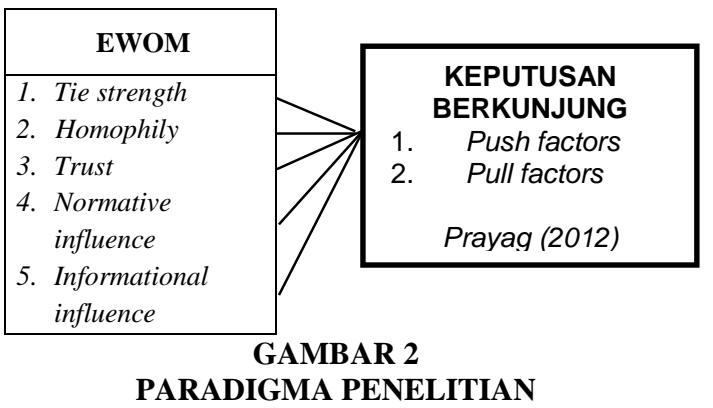

Indikator-indikator dari masing-masing variabel dapat dilihat dari Tabel 2 dan Tabel 3 di bawah ini:

TABEL 2

INDIKATOR EWOM

\begin{tabular}{|c|c|}
\hline Tie strength & $\begin{array}{l}\text { 1. Frequence of communication } \\
\text { 2. Overall importance the contacts } \\
\text { 3. Overall closure of contacts }\end{array}$ \\
\hline Homophily & $\begin{array}{l}\text { 1. The feeling of being liked } \\
\text { 2. The feeling of friends who behave like } \\
\text { me } \\
\text { 3. Thinking that friends who are like me }\end{array}$ \\
\hline Trust & $\begin{array}{l}\text { 1. Trust most contacts } \\
\text { 2. Have confidence on friends } \\
\text { 3. Believe in contacts }\end{array}$ \\
\hline $\begin{array}{c}\text { Normative } \\
\text { influence }\end{array}$ & $\begin{array}{l}\text { 1. Purchase brand that I think others will } \\
\text { approve } \\
\text { 2. Purchase the brand others expect me } \\
\text { to buy } \\
\text { 3. Achieving a sense of belonging by } \\
\text { purchasing same products }\end{array}$ \\
\hline
\end{tabular}




\begin{tabular}{cl}
\hline $\begin{array}{c}\text { Informational } \\
\text { influence }\end{array}$ & $\begin{array}{l}\text { 2. I often adten consult other people } \\
\text { 3. I frequently gather information }\end{array}$ \\
\hline Sumber: Chu dan Kim (2011)
\end{tabular}

TABEL 3

INDIKATOR KEPUTUSAN BERKUNJUNG

\begin{tabular}{cl}
\hline & Cosmopolitan experiences \\
& Novelty \\
& Socialization \\
Push & Escape \& relaxation \\
& Multifarious motives \\
& Cultures experiences \\
\hline & Cultural attractions \& accommodation \\
& Transport and value for money \\
& Cuisinie, restaurant and language \\
& Weather and beach activities \\
& Shopping and entertainment \\
& Scenery and natural attractions
\end{tabular}

Sumber: Prayag (2012)

\subsection{Hipotesis}

Berdasarkan premis yang telah disebutkan, maka hipotesis penelitian dalam penelitian ini adalah sebagai berikut:

"Terdapat pengaruh faktor-faktor yang dominan dalam membentuk EWOM terhadap keputusan berkunjung".

\section{METODE PENELITIAN}

\section{a. Objek Penelitian}

Penelitian dilakukan untuk menganalisis faktor-faktor yang membentuk EWOM dan pengaruhnya terhadap keputusan berkunjung wisatawan di Pulau Langkawi. Di dalam penelitian ini yang menjadi objek penelitian terdiri dari dua variabel. Variabel bebas (X) adalah Elektronik Word of Mouth yang terdiri dari tie strength $\left(\mathrm{X}_{1}\right)$, homophily $\left(\mathrm{X}_{2}\right)$, trust $\left(\mathrm{X}_{3}\right)$, normative influence $\left(\mathrm{X}_{4}\right)$ dan informational influence $\left(\mathrm{X}_{5}\right)$. Sedangkan variabel terikat $(\mathrm{Y})$ adalah push factors $\left(\mathrm{Y}_{1}\right)$, dan pull factors $\left(\mathrm{Y}_{2}\right)$.

Unit analisis dalam penelitian ini adalah wisatawan domestik dan mancanegara yang berkunjung ke destinasi pariwisata Pulau Langkawi.

\subsection{Metode Penelitian}

Berdasarkan variabel-variabel yang diteliti maka metode penelitian yang dipergunakan adalah metode penelitian deskriptif dan verifikatif.

\subsection{Metode Penarikan Sampel}

Ukuran sampel dihitung dengan menggunaan rumus Slovin (Husein Umar, 2003:141). Berdasarkan rumus tersebut, dengan derajat kesalahan sebesar $10 \%$, maka jumlah responden yang dijadikan ukuran sampel dalam penelitian ini ialah sebanyak 100 wisatawan.

\subsection{Teknik Pengumpulan Data}

Teknik pengumpulan data yang digunakan oleh penulis adalah sebagai

berikut:

1.Wawancara

2. Observasi

3. Kuesioner

4. Studi literatur

\subsection{Pengujian Validitas dan Reliabilitas}

Sebelum didistribusikan kepada wisatawan, instrumen penelitian yang berupa kuesioner diuji terlebih dahulu. Uji yang dilakukan meliputi uji validitas dan reliabilitas. Nasution (1987:103) menyatakan reliabilitas merupakan syarat mutlak untuk menentukan pengaruh variabel satu terhadap yang lain. Hasil menunjukan bahwa keseluruhan instrumen penelitian dikatakan valid dan reliabel.

\subsection{Pengujian Hipotesis}

Untuk menguji hipotesis, penelitian ini menggunakan teknik analisis Partial Least Square (PLS). PLS digunakan untuk mengkonfirmasi teori tetapi dapat digunakan untuk menjelaskan ada atau tidaknya hubungan antara variabel laten. PLS dapat menganalisis sekaligus konstruk yang dibentuk dengan indikator refleksif dan formatif.

PLS merupakan model persamaan struktural (structural equation modelling atau SEM) berbasis variance atau component untuk menganalisis hubungan di antara satu variabel yang didasarkan dugaan bahwa hubungan antar variabel yang ditetapkan mengacu serta mempertimbangkan dasar pengetahuan yang telah jelas dimana setiap variabel diasumsikan mewakili konsep teoritis yang direpresentasikan dalam bentuk variabel laten (Ghozali, 2008).

Model penelitian dapat dilihat di Gambar 3.di bawah ini:

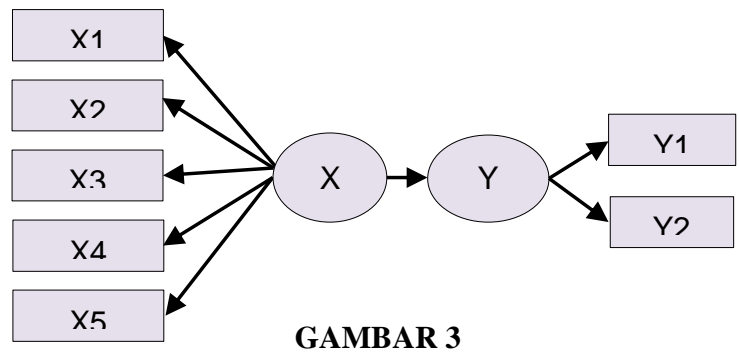

MODEL PENELITIAN MENGGUNAKAN PLS

Keterangan:

$\mathrm{X}=\mathrm{EWOM}$

$\mathrm{X}_{1}=$ Tie strength

$\mathrm{X}_{2}=$ Homophiliy

$\mathrm{X}_{3}=$ Trust

$\mathrm{X}_{4}=$ Normative influence

$\mathrm{X}_{5}=$ Informational influence

$\mathrm{Y}=$ Keputusan berkunjung

$\mathrm{Y}_{1}=$ Push factors

$\mathrm{Y}_{2}=$ Pull factors 
Pengujian hipotesis melalui beberapa kriteria pengukuran yaitu:

1. Uji convergent validity untuk mengukur tingkat akurasi indikator yang digunakan untuk mengukur konstruk atau dimensi melalui pengukuran besarnya korelasi di antara konstruk dengan variabel laten. Untuk menguji convergent validity digunakan standardized loading factor yang menggambarkan besarnya korelasi antar indikator. Nilai loading factor di atas 0,70 dinyatakan sebagai ukuran ideal, nilai 0,50 masih dapat diterima dan nilai di bawah 0,50 harus dikeluarkan dari model. Pengukuran convergent validity dapat juga menggunakan average variance extracted (AVE) yang mempu menunjukkan kemampuan nilai variabel laten. Semakin besar nilai AVE maka semakin tinggi kemampuannya dalam menjelaskan skor pada indikator-indikator yang mengukur variabel laten tersebut.

2. Uji discriminant validity untuk menguji korelasi indikator-indikator suatu konstruk. discriminant validity dievaluasi melalui cross loading kemudian membandingkan nilai AVE dengan kuadran nilai korelasi antara konstruk atau membandingkan skor AVE dengan korelasi antar konstruk.

3. Uji composite validity sebagai metode yang lebih baik dibandingkan dengan nilai cronbach's alpha cenderung menaksir construct reliability yang lebih rendah dibandingkan dengan composite reliability. Interpretasi composite validity adalah $0,70 \mathrm{ke}$ atas dapat diterima, di atas 0,80 dan 0,90 berarti sangat memuaskan.

4. Melihat besaran nilai $\mathrm{R}^{2}$ dimana 0,67 sebagai substansial, 0,33 sebagai moderat dan 0,19 sebagai lemah. Perubahan nilai $\mathrm{R}^{2}$ dapat digunakan untuk melihat apakah pengaruh variabel laten eksogen terhadap variabel laten endogen memiliki pengaruh substantif, yang diukur melalui effect size $f^{2}$.

5. Memvalidasi dengan Goodness of Fit (GoF) sebagai ukuran tunggal untuk memvalidasi performa gabungan di antara model pengukuran dan model struktural. Kisaran GoF adalah antara 0 sampai dengan 1 dengan interpretasi nilai 0,1 kecil, 0,25 moderat dan 0,36 besar.

\begin{tabular}{lll}
\hline IV. HASIL & PENELITIAN & DAN \\
PEMBAHASAN & &
\end{tabular}

\subsection{Hasil Tanggapan Wisatawan Terhadap Elektronik Word of Mouth \\ Rekapitulasi tanggapan wisatawan terhadap keseluruhan sub variabel EWOM dapat dilihat pada Tabel 4 yang disajikan sebagai berikut:}

TABEL 4

REKAPITULASI TANGGAPAN WISATAWAN TERHADAP EWOM

\begin{tabular}{llccc}
\hline No. & Sub Variabel & $\begin{array}{c}\text { Total } \\
\text { Skor }\end{array}$ & $\begin{array}{c}\text { Skor } \\
\text { Rata- } \\
\text { rata }\end{array}$ & $\%$ \\
\hline 1. & Tie strength & 1122 & 374 & 22 \\
2. & Homophily & 981 & 327 & 19 \\
3. & Trust & 1064 & 355 & 20,7 \\
4. & $\begin{array}{l}\text { Normative } \\
\text { influence }\end{array}$ & 951 & 317 & 18,6 \\
5. & $\begin{array}{l}\text { Informational } \\
\text { influence }\end{array}$ & 1008 & 336 & 19,7 \\
\hline & $\quad$ Total & 5126 & 1709 & 100 \\
\hline
\end{tabular}

Sumber: Hasil Pengolahan Data, 2015

Berdasarkan Tabel 4 di atas dapat diketahui bahwa dari lima dimensi EWOM yang mendapat tanggapan paling tinggi dari wisatawan adalah sub variabel tie strength dengan skor rata-rata 374 atau $22 \%$. Sedangkan sub variabel yang mendapat tanggapan paling rendah berdasarkan skor yang diperoleh adalah sebesar 951 yaitu normative influence dengan rata-rata skor 317 atau 18,6\%. Hal tersebut berarti sebagian besar wisatawan yang mengakses SNSs menilai bahwa ikatan yang ada antar pengguna SNSs merupakan ikatan yang penting sehingga semakin kuat terjalin maka semakin banyak pesan-pesan virtual yang dapat dibagikan secara akurat. Hal ini berbanding terbalik dengan sub variabel normative influence yang memiliki skor paling rendah dikarenakan sebagian besar wisatawan memilih destinasi wisata berdasarkan pilihan sendiri dan rendahnya pengaruh yang diberikan orang lain dalam proses pemilihan tersebut.

Semakin kuatnya ikatan yang terjalin menandakan pengguna merasa nyaman secara emosional dan menumbuhkan rasa kepercayaan yang tinggi satu sama lain. Mittal (2008) dalam Chu dan Kim (2011:52) menilai bahwa ikatan yang terjalin di media sosial dapat berubah-ubah berdasarkan kedekatan dan hubungan yang terjalin di antara lingkungan media sosial.

\subsection{Hasil Tanggapan Wisatawan Terhadap Keputusan Berkunjung}

Rekapitulasi tanggapan wisatawan terhadap keseluruhan indikator push factors dapat dilihat pada Tabel 5 yang disajikan sebagai berikut:

TABEL 5

REKAPITULASI TANGGAPAN WISATAWAN TERHADAP PUSH FACTORS

\begin{tabular}{llccc}
\multicolumn{5}{c}{ TERHADAP PUSH FACTORS } \\
\hline $\mathbf{N}$ & \multicolumn{1}{c}{ INDIKATOR } & $\begin{array}{c}\text { TOTAL } \\
\text { SKOR }\end{array}$ & $\begin{array}{c}\text { RATA- } \\
\text { RATA } \\
\text { SKOR }\end{array}$ & $\%$ \\
\hline 1. & $\begin{array}{l}\text { Cosmopolitan } \\
\text { Experiences }\end{array}$ & 320 & 320 & 10,7 \\
2. & $\begin{array}{l}\text { Novelty } \\
\text { S. }\end{array}$ & 370 & 370 & 12,4 \\
4. & $\begin{array}{l}\text { Socialization } \\
\text { Escape and } \\
\text { relaxation }\end{array}$ & 738 & 369 & 24,7 \\
& & 860 & 430 & 28,8 \\
\hline
\end{tabular}




\begin{tabular}{|c|c|c|c|c|}
\hline 5. & $\begin{array}{l}\text { Multifarious } \\
\text { motives }\end{array}$ & 291 & 291 & 9,7 \\
\hline 6. & $\begin{array}{l}\text { Cultural } \\
\text { experiences }\end{array}$ & 409 & 409 & 13,7 \\
\hline & Total & 2988 & 2189 & 100 \\
\hline
\end{tabular}

Sumber: Hasil Pengolahan Data, 2015.

Dari Tabel 5 di atas, dari keenam indikator faktor pendorong, indikator faktor pendorong yang memiliki skor paling tinggi yaitu indikator escape and relaxation sebesar 860 dan presentase skor rata-rata sebesar $28,8 \%$ dari keseluruhan faktor pendorong. Sedangkan indikator yang paling rendah mendapat tanggapan wisatawan adalah multifarious motives yang memperoleh rata-rata skor sebesar 291 atau 9,7\% dari keseluruhan total skor. Hal tersebut berarti sebagian besar wisatawan memiliki keinginan untuk mendapatkan liburan yang santai dan dapat beristirahat dari kejenuhan sehari-hari. Dari hasil tanggapan wisatawan tersebut dapat disimpulkan bahwa Langkawi menawarkan objek wisata yang dapat membuat wisatawan mendapatkan pengalaman berwisata yang menyenangkan sehingga wisatawan memilih Langkawi sebagai destinasi wisatanya.

Rekapitulasi tanggapan wisatawan terhadap keseluruhan indikator pull factors dapat dilihat pada Tabel 6 yang disajikan sebagai berikut:

TABEL 6

REKAPITULASI TANGGAPAN WISATAWAN TERHADAP PULL FACTORS

\begin{tabular}{|c|c|c|c|c|}
\hline \multicolumn{5}{|c|}{ TERHADAP PULL FACTORS } \\
\hline $\begin{array}{l}\mathbf{N} \\
\mathbf{O}\end{array}$ & INDIKATOR & $\begin{array}{c}\text { TOTAL } \\
\text { SKOR }\end{array}$ & $\begin{array}{l}\text { RATA- } \\
\text { RATA } \\
\text { SKOR }\end{array}$ & $\%$ \\
\hline 1. & $\begin{array}{l}\text { Cultural attractions } \\
\text { and accommodation }\end{array}$ & 1453 & 363,3 & 39 \\
\hline 2. & $\begin{array}{l}\text { Transport and value } \\
\text { for money }\end{array}$ & 283 & 283 & 7,6 \\
\hline 3. & $\begin{array}{l}\text { Cuisine, restaurants } \\
\text { and language }\end{array}$ & 618 & 309 & 16,5 \\
\hline 4. & $\begin{array}{l}\text { Weather and beach } \\
\text { activities }\end{array}$ & 719 & 359,5 & 19 \\
\hline 5. & $\begin{array}{l}\text { Shopping and } \\
\text { entertainment }\end{array}$ & 322 & 322 & 8,6 \\
\hline 6. & $\begin{array}{l}\text { Scenery and natural } \\
\text { attractions }\end{array}$ & 347 & 347 & 9,3 \\
\hline & Total & 3742 & 1983,8 & 100 \\
\hline
\end{tabular}

Sumber: Hasil Pengolahan Data,2015.

Dari Tabel 6 di atas, dari keenam indikator dari faktor penarik, indikator faktor penarik yang memiliki skor paling tinggi yaitu indikator cultural attractions and accommodation sebesar 1453 dan presentase skor rata-rata sebesar $39 \%$ dari keseluruhan faktor penarik. Sedangkan indikator yang paling rendah mendapat tanggapan wisatawan adalah transport and value for money yang memperoleh rata-rata skor sebesar 283 atau $7,6 \%$ dari keseluruhan total skor. Hal tersebut membuktikan bahwa Langkawi memiliki atraksi kebudayaan yang mengesankan sehingga menjadi faktor penarik yang ditanggapi dengan sangat baik oleh wisatawan.
Indikator dari faktor penarik yang paling rendah ditanggapi oleh wisatawan adalah transport and value for money yang berarti Langkawi memiliki fasilitas transportasi umum yang kurang memadai sehingga menjadi salah satu kelemahan dari Langkawi.

\subsection{Analisis Faktor Elektronik Word of Mouth dalam Mempengaruhi Keputusan Berkunjung}

Pengujian ini dilakukan untuk memprediksi model dan menganalisis faktor-faktor yang membentuk Elektronik Word of Mouth serta dampaknya terhadap keputusan berkunjung. Untuk menganalisis nya maka dilakukan perhitungan partial least square-path modelling dengan aplikasi XLSTAT PLS-PM 2014. Evaluasi model dalam PLS-PM dilakukan dalam dua tahap yaitu outer model atau model pengukuran dan evaluasi terhadap inner model atau model struktural.

Berikut adalah nilai reliability item yang dapat dilihat pada kolom standardized loading pada Tabel 7 di bawah ini:

TABEL 7

RELIABILITY ITEM

\begin{tabular}{clc}
\hline $\begin{array}{c}\text { Latent } \\
\text { Variabel }\end{array}$ & \multicolumn{1}{c}{$\begin{array}{c}\text { Manifest } \\
\text { Variabel }\end{array}$} & $\begin{array}{c}\text { Standardized } \\
\text { Loadings }\end{array}$ \\
\hline & Tie Strength & 0,580 \\
& Homophily & 0,773 \\
Elektronik & Trust & 0,757 \\
Word of & Normative & 0,789 \\
Mouth & $\begin{array}{l}\text { Influence } \\
\text { Informative }\end{array}$ & 0,624 \\
& Influence & \\
\hline Keputusan & Push Factors & 0,923 \\
Berkunjung & Pull Factors & 0,859 \\
\hline
\end{tabular}

Berdasarkan Tabel 7 di atas, dapat digambarkan bahwa loading factor (standardized loading) Elektronik Word of Mouth yang terdiri dari tie strength, homophily, trust, normative influence dan informative influence memiliki nilai di atas 0,5 sehingga indikator tersebut dikatakan valid. Selain itu variabel keputusan berkunjung yang memiliki loading factor (standardized loading) terdiri dari push factors sebesar 0,923 dan pull factors sebesar 0,859 memiliki nilai di atas 0,5 sehingga dapat dikatakan valid. Dari hasil realibility item di atas maka dapat disimpulkan semua dimensi Elektronik Word of Mouth dan keputusan berkunjung dikatakan valid sebagai indikator untuk mengukur konstrak atau variabel masing-masing.

Berikut adalah Tabel 8 menunjukkan nilai composite reliability: 
TABEL 8

COMPOSITE RELIABILITY

\begin{tabular}{cccc}
\hline $\begin{array}{c}\text { Latent } \\
\text { Variabel }\end{array}$ & $\begin{array}{c}\text { Dimension } \\
\text { s }\end{array}$ & $\begin{array}{c}\text { Cronbach's } \\
\text { Alpha }\end{array}$ & $\begin{array}{c}\text { D.G. rho } \\
(\text { PCA })\end{array}$ \\
\hline $\begin{array}{c}\text { Elektronik } \\
\begin{array}{c}\text { Word of } \\
\text { Mouth }\end{array}\end{array}$ & 5 & 0,755 & 0,837 \\
\hline $\begin{array}{c}\text { Keputusan } \\
\text { berkunjung }\end{array}$ & 2 & 0,746 & 0,887 \\
\hline
\end{tabular}

Tabel 8 menunjukan bahwa nilai cronbach's alpha dan D.G rho (PCA) untuk variabel Elektronik Word of Mouth sebesar 0,755 dan 0,837 sehingga dikatakan dapat diterima. Variabel keputusan berkunjung memperoleh nilai 0,746 dan 0,887, dengan demikian variabel keputusan berkunjung memiliki nilai diatas 0,7 sehingga dapat dikatakan variabel memiliki reabilitas atau keterandalan yang baik sebagai alat ukur.

Berikut adalah Tabel 9 yang menunjukkan nilai convergent validity:

TABEL 9

CONVERGENT VALIDITY

\begin{tabular}{cc}
\hline Latent Variable & $\begin{array}{c}\text { Mean Communalities } \\
\text { (AVE) }\end{array}$ \\
\hline $\begin{array}{c}\text { Elektronik Word of } \\
\text { Mouth }\end{array}$ & 0,504 \\
$\begin{array}{c}\text { Keputusan } \\
\text { berkunjung }\end{array}$ & 0,794 \\
\hline
\end{tabular}

Berdasarkan Tabel 9 Menunjukkan bahwa nilai AVE untuk Elektronik Word of Mouth sebesar 0,504 dan nilai AVE untuk keputusan berkunjung sebesar 0,794. Nilai AVE untuk Elektronik Word of Mouth adalah 0,504 sehingga konstrak Elektronik Word of Mouth memiliki convergent validity yang baik dimana variabel laten dapat menjelaskan rata-rata lebih dari setengah variance dari indikator-indikatornya. Nilai AVE untuk keputusan berkunjung berada diatas 0,5 sehingga konstrak keputusan berkunjung memiliki convergent validity yang baik dimana variabel laten dapat menjelaskan rata-rata lebih dari setengah variance dari indikator-indikatornya.

Berikut Tabel 10 menunjukkan discriminant validity:

TABEL 10

DISCRIMINANT VALIDITY

\begin{tabular}{lcc}
\hline & $\begin{array}{c}\text { Elektronik Word } \\
\text { of Mouth }\end{array}$ & $\begin{array}{c}\text { Keputusan } \\
\text { Berkunjung }\end{array}$ \\
\hline Tie Strength & $\mathbf{0 , 5 8 0}$ & 0,142 \\
Homophily & $\mathbf{0 , 7 7 3}$ & 0,209 \\
Trust & $\mathbf{0 , 7 5 7}$ & 0,155 \\
Normative & $\mathbf{0 , 7 8 9}$ & 0,268 \\
Influence & & \\
Informative & $\mathbf{0 , 6 2 4}$ & 0,193 \\
Influence & & \\
Push Factors & 0,285 & $\mathbf{0 , 9 2 3}$ \\
Pull Factors & 0,214 & $\mathbf{0 , 8 5 9}$ \\
\hline
\end{tabular}

Berdasarkan Tabel 10 menunjukkan bahwa nilai discriminant validity atau loading factor untuk indikator homophily dan normative influence memiliki korelasi yang lebih tinggi dengan keputusan berkunjung dengan nilai 0,773 dan 0,789 dibandingkan indikator tie strength, trust dan informative influence. Hal ini menunjukkan bahwa indikator homophily dan normative influence mampu menjelaskan varian yang lebih tinggi.

Sedangkan nilai loading factor semua indikator keputusan berkunjung memiliki korelasi yang sangat tinggi dengan variabel keputusan berkunjung. Hal ini menunjukkan bahwa variabel keputusan berkunjung mampu menjelaskan varian yang tinggi dengan dua indikator yaitu push dan pull factors.

Untuk melihat signifikansi hubungan antara konstrak dapat dilihat dari koefisien jalur (path coefficient). Untuk melilhat signifikansi path coefficient dapat dilihat dari t-test (critical ratio) yang diperoleh dari proses bootstrapping. Berikut adapun Tabel 11 adalah hasil path coefficient.

TABEL 11

PATH COEFFICIENT

$\mathrm{R}^{2}$ Keputusan Berkunjung/ 1

\begin{tabular}{|c|c|c|c|c|c|c|c|c|}
\hline $\mathbf{R}^{2}$ & \multicolumn{2}{|l|}{$\mathbf{F}$} & \multicolumn{2}{|c|}{$\begin{array}{l}\text { Pr } \\
\text { F }\end{array}$} & \multicolumn{2}{|c|}{$\begin{array}{l}R^{2} \\
\text { (Bootstr } \\
\text { ap) }\end{array}$} & $\begin{array}{l}\text { Standa } \\
\text { rd } \\
\text { error }\end{array}$ & $\begin{array}{l}\text { Critcal } \\
\text { Ratio } \\
\text { (CR) }\end{array}$ \\
\hline $\begin{array}{l}0,0 \\
81\end{array}$ & 8,60 & & & & 0,115 & & 0,052 & 1,552 \\
\hline \multicolumn{9}{|c|}{ Path coefficients (Keputusan Berkunjung / 1} \\
\hline $\begin{array}{l}\text { Latent } \\
\text { Variabl }\end{array}$ & & $\begin{array}{l}\mathrm{Va} \\
\mathrm{e}\end{array}$ & & & $\begin{array}{l}\text { ndar } \\
\text { ror }\end{array}$ & $\mathbf{t}$ & $\begin{array}{l}\mathbf{P r} \geq \\
|\mathbf{t}|\end{array}$ & $\mathbf{f}^{2}$ \\
\hline $\begin{array}{l}\text { Elektron } \\
k \text { Word } \\
\text { Mouth }\end{array}$ & & & & & & $\begin{array}{l}2,93 \\
4\end{array}$ & $\begin{array}{l}0,00 \\
4\end{array}$ & $\begin{array}{l}0,08 \\
8\end{array}$ \\
\hline
\end{tabular}

Tabel 11 menunjukkan nilai t- statistic untuk variabel Elektronik Word of Mouth dengan p-value $0,000<0,05$ sehingga dapat dikatakan bahwa Elektronik Word of Mouth memiliki pengaruh yang positif terhadap keputusan berkunjung. Sedangkan pengujian simultan antara variabel Elektronik Word of Mouth terhadap keputusan berkunjung dapat dilihat dari statistic $\mathrm{F}$ dengan dengan nilai $\mathrm{p}$ value adalah $0,000<0,05$. Hasilnya secara simultan variabel Elektronik Word of Mouth berpengaruh terhadap keputusan berkunjung.

Model persamaan antara Elektronik Word of Mouth terhadap keputusan berkunjung adalah sebagai berikut : Keputusan berkunjung = 0.284140835708197*Elektronik Word of Mouth.

Besarnya kontribusi variabel Elektronik Word of Mouth terhadap keputusan berkunjung dapat dilihat dari nilai koefisien jalurnya pada Gambar 4:

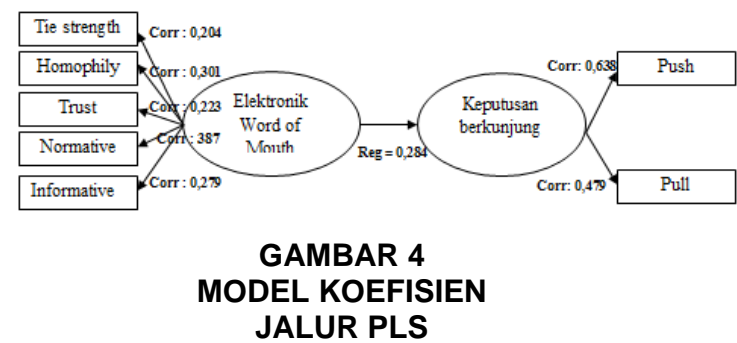


Berikut adalah Tabel 12 menunjukkan nilai $\mathrm{R}^{2}$ :

TABEL 12

$\mathrm{R}^{2}$ ELEKTRONIK WORD OF MOUTH ELEKTRONIK

\begin{tabular}{lcc}
\hline & \multicolumn{2}{c}{ R $^{2}$ ELEKTRONIK WORD OF MOUTH } \\
\hline & WORD OF MOUTH \\
\hline Correlation & 0,284 \\
Path Coefficient & 0,284 \\
Correlation * path & 0,081 \\
coefficient & \\
Contribution to $\mathrm{R}^{2}$ & 100.000 \\
$\%$ & & \\
& Cumulative \% & 100.000 \\
\hline
\end{tabular}

Tabel 12 di atas menunjukan bahwa Elektronik Word of Mouth memiliki kontribusi lemah terhadap keputusan berkunjung berdasarkan kriteria Chin (1998) nilai $\mathrm{R}^{2} 0,67,0,33$ dan 0,19 dikelompokkan sebagai pengaruh kuat, sedang dan lemah. Hal tersebut menggambarkan bahwa variabel Elektronik Word of Mouth memiliki pengaruh yang lemah terhadap keputusan berkunjung wisatawan. Sedangkan menurut penilaian lain dari nilai effect size $f^{2}$ sebesar 0,088 yang berarti memiliki pengaruh kecil terhadap level struktural.

Berikut adalah Tabel 13 menunjukkan nilai Goodness of Fit (GoF):

TABEL 13

GOODNESS OF FIT

\begin{tabular}{lllll}
\hline & GoF & $\begin{array}{l}\text { GoF } \\
\text { (Bootstra } \\
\text { p) }\end{array}$ & $\begin{array}{l}\text { Standar } \\
\text { d error }\end{array}$ & $\begin{array}{l}\text { Critica } \\
\text { l Ratio } \\
\text { (CR) }\end{array}$ \\
\hline Absolut & $\mathbf{0 , 2 1}$ & 0,249 & 0,061 & 3,557 \\
$e$ & $\mathbf{8}$ & 0,782 & 0,106 & 8,808 \\
Relativ & $\mathbf{0 , 9 3}$ & 0,973 & 0,044 & 22,253 \\
$e$ & $\mathbf{4}$ & 0,803 & 0,097 & 9,687 \\
Outer & $\mathbf{0 , 9 9}$ & & & \\
model & $\mathbf{1}$ & & & \\
Inner & $\mathbf{0 , 9 4}$ & & & \\
model & $\mathbf{2}$ & & & \\
\hline
\end{tabular}

Tabel 13 menunjukkan bahwa nilai GoF hampir seluruhnya bernilai lebih dari 0,36 sehingga dikategorikan sebagai GoF besar, artinya model sangat tinggi (memiliki kemampuan yang tinggi) dalam menjelaskan data empiris.

\subsection{Implikasi Hasil Temuan}

Temuan yang bersifat teoritik pada penelitian ini adalah bahwa berdasarkan hasil penelitian, penulis memperkuat konsep keputusan berkunjung yang terdiri dari faktor pendorong dan penarik (Prayag, 2012). Faktor pendorong memiliki enam indikator yaitu cosmopolitan experiences, novelty, socialization, escape and relaxation, multifarious motives dan cultural experiences. Sedangkan faktor penarik memiliki enam indikator yaitu cultural attractions and accommodation, transportation and value for money, cuisine, restaurants and language, weather and beach activities, shopping and entertainment dan scenery and natural attractions. Dalam penelitian ini mengadaptasi kedua faktor tersebut untuk menilai sejauh mana faktor tersebut berperan dalam kegiatan wisatawan dalam waktu kunjungannya di Pulau Langkawi. Selain itu penulis memperkuat konsep Chu dan Kim (2011) bahwa EWOM merupakan elemen yang terjadi dan memiliki peranan sebagai media periklanan melalui media sosial. EWOM memiliki lima dimensi di lingkup social networking sites yaitu tie strength, homophily, trust, normative influence dan informative influence. Namun penelitian menghasilkan pengaruh yang tidak signifikan EWOM terhadap keputusan berkunjung wisatawan di Pulau Langkawi. Hal ini disebabkan oleh banyaknya faktor lain yang mempengaruhi keputusan berkunjung wisatawan antara lain metode online marketing lainnya maupun faktor lain yang tidak diteliti.

Temuan yang bersifat empirik antara lain:

1. Fenomena EWOM yang terjadi di media elektronik mengenai wisata Pulau Langkawi meliputi beberapa dimensi yaitu tie strength, homophily, trust, normative influence dan informative influence. Normative influence merupakan faktor yang paling tinggi dalam membentuk EWOM. Normative influence merupakan pengaruh normative seperti informasi umum yang tersebar mengenai Pulau Langkawi yang terdiri dari fasilitas, atraksi, kegiatan, transportasi yang dibicarakan di forum wisata seperti tripadvisor maupun blog pribadi.

2. Keputusan berkunjung yang terdiri dari faktor pendorong dan penarik masing-masing terdapat enam indikator. Faktor yang memberikan kontribusi paling besari dari faktor pendorong yaitu escape and relaxation dimana wisatawan berkunjung ke Pulau Langkawi untuk menjauhkan diri dari rutinitas dan bersantai menikmati kegiatan wisata. Sedangkan faktor penarik yang memberikan kontribusi paling besar yaitu cultural attractions and accommodation dikarenakan Pulau Langkawi memiliki atraksi budaya yang menarik dan akomodasi yang sangat memadai untuk para wisatawan yang berkunjung.

3. Dari hasil pengujian didapatkan lima dimensi dari EWOM yang terjadi di media sosial terkait wisata Pulau Langkawi dan berpengaruh positif terhadap keputusan berkunjung yaitu tie strength, homophily, trust, normative influence dan informative influence. Kelima dimensi tersebut memiliki pengaruh positif namun lemah terhadap keputusan berkunjung dikarenakan ada faktor-faktor lain yang tidak diteliti yang terjadi di lapangan. 


\section{KESIMPULAN \& REKOMENDASI}

Berdasarkan hasil penelitian yang dilakukan oleh peneliti melalui analisis deskriptif dan verfifikatif dengan menggunakan PLS, maka diambil kesimpulan sebagai berikut:

1. EWOM yang tersebar di Pulau Langkawi sangat luas dan beragam, hal tersebut dikarenakan banyaknya media interaktif dan praktis antara penulis dan pembaca di internet yang mampu menjadi wadah EWOM seperti tripadvisor, lonely planet, asiawebdirect, virtualtourist yang memungkinkan wisatawan mengakses informasi secara detail tentang Pulau Langkawi.

2. Keputusan berkunjung wisatawan yang terdiri dari push and pull factors di Pulau Langkawi memiliki masing-masing indikator. Indikator push factor yang memiliki tanggapan paling tinggi adalah escape and relaxation yang berarti wisatawan yang berkunjung ke Pulau Langkawi memiliki hasrat untuk menjauhkan diri dari rutinitas dan menikmati kegiatan wisatanya. Sedangkan dari indikator pull factors yang memiliki tanggapan paling tinggi adalah cultural attractions and accommodation yang berarti Pulau Langkawi memiliki kapabilitas sebagai tempat yang menyediakan beragam acara festival maupun acara besar lainnya yang menyangkut wisata budaya dan atraksi wisata alam serta ketersediaan akomodasi yang lengkap menjadi faktor penarik wisatawan yang berkunjung ke Pulau Langkawi.

3. Faktor dari EWOM yang dominan membentuk EWOM adalah homophily dan normative influence. Hal ini dikarenaan kesamaan pikiran dan tingkah laku wisatawan menjadi hal yang paling penting dalam membentuk EWOM yang kemudian akan diikuti informasi yang tersebar baik itu bersifat umum maupun terinci yang ada di berbagai media.

4. EWOM mengenai Langkawi memiliki pengaruh positif yang lemah terhadap keputusan berkunjung wisatawan. EWOM berperan sebagai media periklanan antara calon wisatawan dengan wisatawan yang pernah mengunjungi Langkawi, namun tidak memiliki dampak yang signifikan dikarenakan banyak faktor yang mempengaruhi keputusan berkunjung yang tidak diteliti dalam penelitian ini.

Berdasarkan hasil penelitian yang telah dilakukan, maka penulis merekomendasikan halhal sebagai berikut:

1. EWOM yang berkembang di media internet mengenai Langkawi sudah baik sehingga sebaiknya menjadi strategi pemasaran yang juga dilakukan oleh pemerintah Langkawi. Hal tersebut dapat diwujudkan dengan adanya media interaktif seperti blog, tour and travel advisor, program membership untuk komunitas-komunitas tertentu sehingga informasi yang berkembang mendapatkan timbal balik dan dapat dikendalikan pula oleh pengelola destinasi.

2. Wisatawan yang berkunjung ke Pulau Langkawi karena faktor pendorong nya yaitu menjauhkan diri dari rutinitas dan menikmati waktu berwisata. Sedangkan faktor penarik nya yaitu berbagai atraksi budaya dan alam serta ketersediaan akomodasinya yang memadai. Oleh karena itu fasilitas umum dan atraksi wisata yang ada di Langkawi perlu ditingkatkan lagi termasuk sistem pelayanannya, kebersihan dan keamanannya untuk mempertahankan wisatawan berkunjung di sana.

3. Homophily dan normative influence merupakan faktor yang dominan membentuk EWOM. Kesamaan pikiran, perilaku dan keinginan serta informasi umum mengenai pariwisata di Langkawi memberikan dampak paling besar terbentuknya EWOM. Oleh karena itu untuk menciptakan opini yang baik dari wisatawan yang pernah berkunjung ke Langkawi, keadaan pariwisata berupa fasilitas, transportasi, keamanan dan pelayanan sebaiknya lebih dikembangkan lagi. Sedangkan faktor EWOM lainnya seperti tie strength, trust dan informational influence perlu ditingkatkan salah satu nya dengan cara program membership bagi komunitas wisatawan virtual.

4. Dengan adanya pengaruh positif yang lemah dari EWOM terhadap keputusan berkunjung wisatawan, dapat diketahui EWOM memiliki peranan penting khususnya sebagai media pemasaran dari wisatawan ke wisatawan. Oleh sebab itu sebaiknya terdapat pengelolaan yang khusus di media internet sehingga pengawasan EWOM di media sosial dapat terpantau oleh pengelola Langkawi dan menciptakan hubungan timbal balik yang sebaik-baiknya.

\section{DAFTAR PUSTAKA}

Cheung, C. M., \& Thadani, D. R. (2010). The Effectiveness of Electronic Word-ofMouth Communication: A Literature Analysis. 23rd Bled eConference eTrust: Implications for the Individual, Enterprises and Society. Bled, Solvenia.

Chu, S.-C., \& Kim, Y. (2011). Determinants of Consumer Engagement In Electronic Word-Of-Mouth (Ewom) In Social 
Networking Sites. International Journal od Advertising.

Hennig-Thurau, T., Malthouse, E. C., Friege, C., Gensler, S., Lobschat, L., Rangaswamy, A., et al. (2010). The Impact of New Media on Customer Relationships. Journal of Service Research.

Jalilvand, M. R., Samiei, N., Dini, B., \& Manzari, P. Y. (2012). Examining the structural relationships of electronic word of mouth, destination image, tourist attitude toward destination and travel intention: An integrated approach. Journal of Destination Marketing \& Management.

Kaplan, A. M., \& Haenlein, M. (2010). Users of the world, unite! The challenges and opportunities of Social Media.

Litvin, S., Goldsmith , R., \& Pan, B. (2008). Electronic word-of-mouth in hospitality and tourism management. Tourism Management.

Nasution, S. (1987). Metode Research. Bandung: Jemmars.

Parra-López, E., Bulchand-Gidumal, J., Gutiérrez-Taño, D. \& Díaz-Armas, R. (2011). Intentions to use social media in organising and taking vacation trips. Computers in Human Behaviour. 27(2): 640-654.

Prayag, Girish. (2012). Senior Travelers' Motivations And Future Behavioral Intentions: The Case of Nice. Journal of Travel \& Tourism Marketing.

Schmoll GA (1977). Tourism Promotion. London: Tourism International Press.

Sugiyono. (2010). Metode Penelitian Kuantitatif Kualitatif \& RND. Bandung: Alfabeta.

Sugiyono. 2012. Metode Penelitian Kuantitatif dan R\&D. Alfabeta, Bandung.

Taylor, G. David., Strutton, David. (2012). Do Microblog Postings Influence Consumer Perceptions of Retailers' E'Servicescapes?. Business Faculty Publications.

Thor, S. (2013). Electronic Word-of-Mouth: Increasing the Velocity and Reach of Traditional Word-of-Mouth. George Fox University.

Xiang, Z., \& Gretzel, U. (2009). Role Of Social Media In Online Travel Information Search. Tourism Management.

\section{Website}

http://www2.unwto.org diakses pada Juli 2014

http://www.motour.gov.m diakses pada Juli 2014 corporate.tourism.gov.my www.visitkedah.com.my, 2013 wonderfulmalaysia.com, 2013 lada.gov.my www.ama.org, 2013 
